\title{
Confirmation of the presence of Janicea antiguensis (Chace, 1972) (Decapoda: Barbouriidae) in northeastern and eastern Brazil
}

\author{
Bruno W. Giraldes, Petrônio A. Coelho Filho, Petrônio A. Coelho ${ }^{\dagger}$ and Arthur Anker
}

(BWG) (PAC) Laboratório de Carcinologia, Departamento de Oceanografia, Museu Oceanográfico da Universidade Federal de Pernambuco (MOUFPE). Avenida Arquitetura, s/n, Cidade Universitária, 50670-901, Recife, Pernambuco, Brazil. ${ }^{\dagger}$ in memoriam. E-mail: b.w.giraldes@hotmail.com (PACF) Departamento de Engenharia de Pesca, Universidade Federal de Alagoas. Avenida Divaldo Suruagy, s/n, Centro, 57200-000, Penedo, Alagoas, Brazil. E-mail: petroniocoelhofilho@gmail.com (AA) Laboratório de Zoobentos, Instituto de Ciências do Mar (Labomar), Universidade Federal do Ceará. Avenida da Abolição, 3207, Meireles, 60165-081, Fortaleza, Ceará, Brazil. E-mail: arthuranker7@yahoo.com

\section{Abstract}

The barbouriid shrimp Janicea antiguesis (Chace, 1972) is reported from Porto de Galinhas and Tamandaré in Pernambuco and Guarapari in Espírito Santo, Brazil. These records confirm the presence of J. antiguensis in northeastern and eastern Brazil, considerably extending its Brazilian range from Fernando de Noronha to southern Espírito Santo and also representing the first record of this species from mainland coastal reefs. In Brazil, J. antiguensis occurs in or near marine reef caves, typically at depths between 5 and $15 \mathrm{~m}$, and can be most easily observed while scuba diving at night. Colour photographs of $J$. antiguensis from various Atlantic localities are provided and its colour pattern is compared to that of the closely related Indo-West Pacific barbouriid shrimp, Parhippolyte misticia (Clark, 1989). Some in situ observations are provided for the Porto de Galinhas population of $J$. antiguensis. Multiple observations of pairs with both individuals brooding embryos at different developmental stages suggest protandric simultaneous hermaphroditism in J. antiguensis.

Key words: Caridea, hermaphroditism, marine cave, new records, shrimp.

\section{Introduction}

The marine cave shrimp Janicea antiguensis (Chace, 1972) belongs to the family Barbouriidae Christoffersen, 1987, a morphologically relatively homogeneous group of three genera and seven species: Barbouria cubensis (von Martens, 1872), B. yanezi Mejía, Zarza and López, 2008, J. antiguensis (Chace,
1972), Parhippolyte uveae Borradaile, 1899, P. misticia (Clark, 1989), P. cavernicola Wicksten, 1996 and P. sterreri (Hart and Manning, 1981) (De Grave and Fransen, 2011). All barbouriid shrimps are associated with relatively shallow marine and anchialine caves and similar crevicular habitats (Manning and Hart, 1984; Wicksten, 1996).

$$
\text { Janicea antiguensis was originally }
$$


described by Chace (1972) as Barbouria antiguensis from Antigua, where it was found at night a meter or so below the water surface on algae-covered seawalls. Subsequently, J. antiguensis was recorded from marine caves and wall crevices from several localities on both sides of the Atlantic Ocean, including Bermuda, Cozumel and Mexico's Yucatan Peninsula, São Tomé and Príncipe, Cape Verde, and Fernando de Noronha off northeastern Brazil (Iliffe et al., 1983; Manning and Hart, 1984; Kensley, 1988; Iliffe, 1993; RamosPorto and Coelho, 1993; Hobbs III, 1994; d'Udekem d'Acoz, 2000; Wirtz, 2004; Coelho et al., 2006; Alves et al., 2008).

Over a period of several years (20042011), approximately 230 individuals of a caridean shrimp that by its general appearance and colour pattern matched J. antiguesis (cf. Wirtz and Debelius, 2003) were observed at night inside caves while scuba diving on shallow reefs off Porto de Galinhas, south of Recife, Pernambuco, northeastern Brazil. Six specimens of this shrimp were collected in March 2011 and after a morphological examination confirmed to be J. antiguensis. These specimens confirm the presence of $J$. antiguensis in Brazil and also constitute the first records of this species for the Brazilian mainland and for the state of Pernambuco. In addition, eight individuals of $J$. antiguensis were observed during nocturnal dives on the reefs of Tamandaré, $40 \mathrm{~km}$ south of Porto de Galinhas. Finally, Peter Wirtz (Universidade do Algarve, Portugal) kindly informed us that a specimen of $J$. antiguensis from Guarapari, Espírito Santo, was deposited in the collections of Museu de Zoologia da Universidade de São Paulo, São Paulo, Brazil (MZUSP), representing the southern-most record of this species in the southwestern Atlantic Ocean.

Material and Methods

The nocturnal visual surveys were conducted on the reefs off Porto de Galinhas

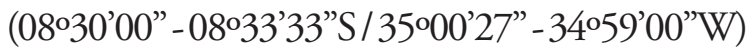

and Tamandaré (08047'20”S / 3506 $45^{\circ}$ ”W), Pernambuco, northeastern Brazil, in June 2004 to May 2005, October to November 2008, and February to March 2011. The six specimens of $J$. antiguensis collected manually off Porto de Galinhas in March 2011 were transported alive to Laboratório de Carcinicultura, Universidade Federal de Alagoas, Penedo, for photography and confirmation of identification using accounts of Chace (1972: 107) and Manning and Hart (1984: 657). The Pernambuco material was preserved in $70 \%$ ethanol and deposited in the crustacean collection of the Museu de Oceanografia, Departamento de Oceanografia, Universidade Federal de Pernambuco, Recife, Pernambuco, Brazil (MOUFPE). Additional material from Fernando de Noronha and Espírito Santo (MZUSP) was also briefly examined. Drawings were made under a stereomicroscope with the aid of a drawing tube. Carapace length (CL, in $\mathrm{mm}$ ) was measured with a digital vernier calliper $(0.01 \mathrm{~mm})$ from the base of the rostrum to the posterior margin of the carapace.

Results

\section{Systematics}

Family Barbouriidae Christoffersen, 1987 Genus Janicea Manning and Hart, 1984

Janicea antiguensis (Chace, 1972)

(Figs. 1, 2A-D)

Barbouria antiguensis Chace, 1972: 107, figs. 41-42; Hobbs III, 1978: 99; Hart and Manning, 1981: 441; Iliffe et al. 1983: 141.

Janicea antiguensis - Manning and Hart, 1984: 657, fig. 2; Kensley, 1988: 698; Hobbs III, 1994: 98; d'Udekem d'Acoz, 2000: 1163, fig. 1; Wirtz, 2004: 84; Coelho et al., 2006: 53; Mejía-Ortiz et al., 2006: 13; Alves et al., 2008: 50 .

Material examined: Brazil. 2 nonovigerous specimens (CL 7.7 and $9.74 \mathrm{~mm}$ ), 4 ovigerous specimens (CL 10.50-11.86 


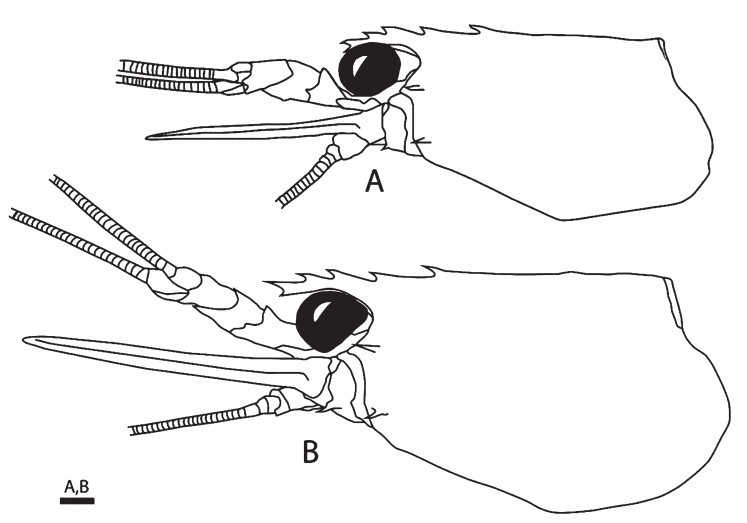

Figure 1. Janicea antiguensis (Chace, 1972) from reef caves off Porto de Galinhas, Pernambuco, northeastern Brazil, anterior part of the body of two specimens (MOUFPE 15014): (A) non-ovigerous specimen (CL $7.7 \mathrm{~mm}$ ); (B) ovigerous specimen (CL $11.12 \mathrm{~mm}$ ).

$\mathrm{mm})$, Pernambuco, off Porto de Galinhas,

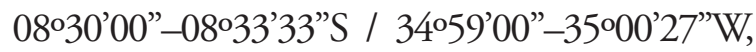
marine reef, on cave walls and roofs, depth 5-10 m, leg. B.W. Giraldes et al., 17 March 2011, MOUFPE 15014, MOUFPE 15015; 1 ovigerous female (CL not measured), Guarapari, Espírito Santo, leg. P. Wirtz, vi.2006, depth 30 m, MZUSP 17014; 1 nonovigerous specimen and 1 ovigerous specimen (CL not measured), Fernando de Noronha, vii.1969, MZUSP 8967 (P.A. Coelho det. Barbouria antiguensis).

Diagnosis (modified from Manning and Hart, 1984): Carapace with antennal and branchiostegal teeth; rostrum slender, about five times as long as high, short, extending to about end of basal article of antennular peduncle, with three to four dorsal (one or two postorbital) teeth and one ventral tooth. Eyes large, well-pigmented, cornea broader than eyestalk. Anterior four pleura rounded, fifth pleuron acute posteroventrally. Telson with two pairs of dorsal spines and three pairs of terminal spines, mesial spines longest. Mandible lacking incisor process, with three-jointed palp. First and second pereopods chelate; merus, carpus, and propodus of second pereopod multiarticulate; third to fifth pereopods with carpus and propodus multiarticulate. Endopod of male first pleopod without appendix interna, with distal coupling hooks; endopod of male second pleopod with appendix masculina longer than appendix interna. Gill/exopod formula: six epipods (on coxae of Mxp2, Mxp3, P1-4); five pleurobranchs (above P15); two arthrobranchs (Mxp3); 1 podobranch (Mxp2).

Colour pattern: Carapace, abdomen and tail fan semi-transparent, with some red or orange-red chromatophores present between pleopods and walking legs; each pleuron with relatively narrow, red band running transversely along posterior margin, but not extending to ventral margin; third to fifth abdominal segments also with small patch of white chromatophores dorsally; antennular and antennal peduncles semi-transparent, with reddish lateral margins, lateral antennular and antennal flagella reddish; mesial antennular flagella mostly whitish with some red colour; third maxilliped and first and second pereiopods reddish; third to fifth pereopods mostly white, with some reddish chromatophores proximally; telson and uropods semi-transparent, with reddish margins; fresh eggs pale olive-green (Fig. 2A). Individuals kept in aquariums with artificial lighting (photoperiod 12:12 h) displayed essentially the same colour pattern as individuals observed in situ in semi-dark caves. The individuals from Espírito Santo, Cape Verde and Canary Islands are very similar in the general colour pattern (Figs. 2B-D), although freshly laid eggs tend to be yellow in the eastern Atlantic individuals (Figs. 2C, D) and not green as in some western Atlantic individuals, e.g., those from Pernambuco (Fig. 2A).

Distribution: Amphi-Atlantic (Fig. 3); Eastern Atlantic: São Tomé and Príncipe (Wirtz, 2004); Cape Verde Islands (d'Udekem d'Acoz, 2000); Canary Islands (based on coloured photographs, Fig. 2C; see also Wirtz, 2004); Western Atlantic: Antigua (Chace, 1972); Bermuda (Hart and Manning, 1981; Iliffe et al., 1983); Cozumel Island and Yucatan Peninsula (Kensley, 1988; Iliffe, 1993; Hobbs III, 1994; Mejía-Ortiz et al., 2006); Bonaire (A. Anker, pers. obs. based on colour photographs); 

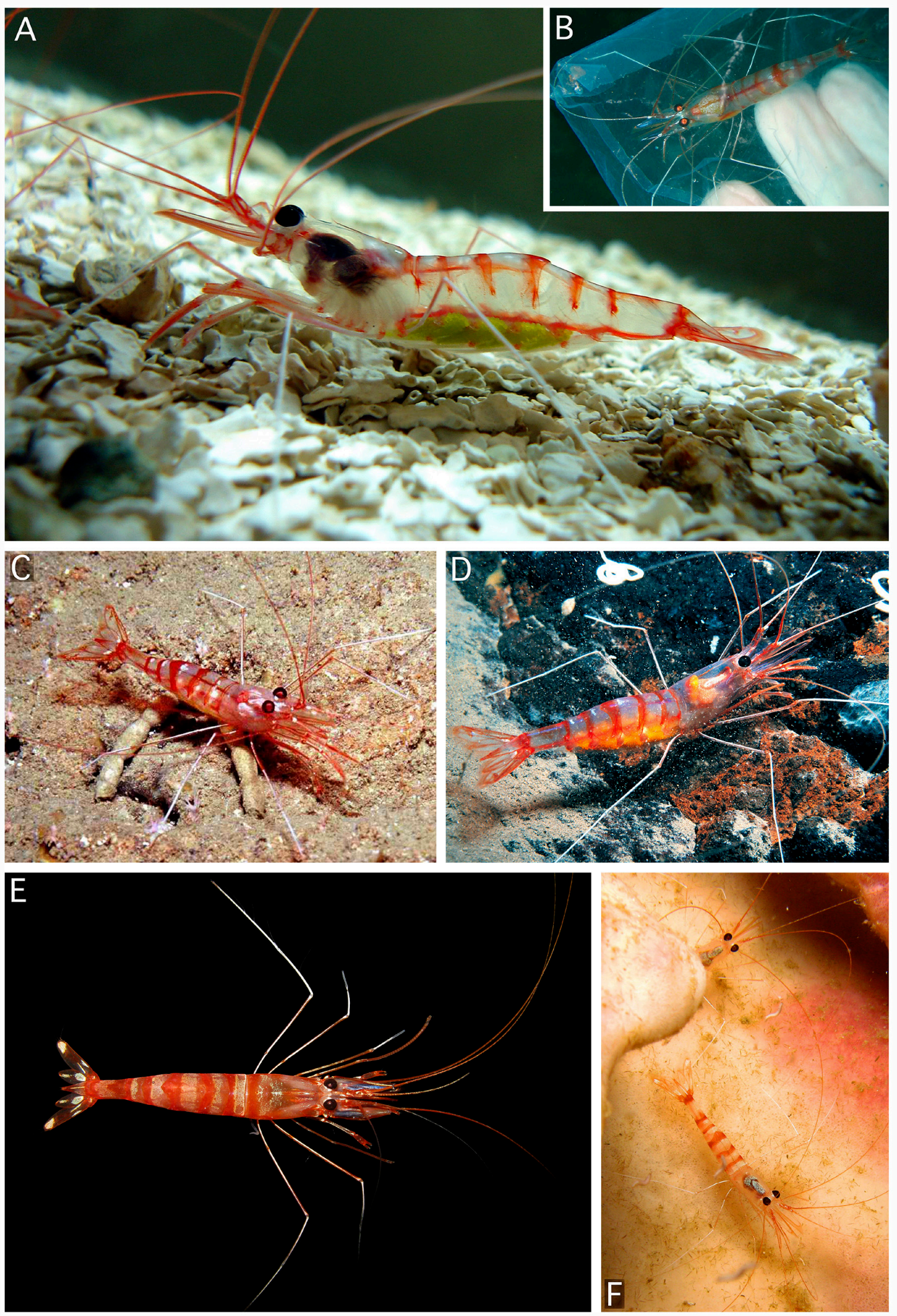

Figure 2. Janicea antiguensis (Chace, 1972) [A-D] and Parhippolyte misticia (Clark, 1989) [E, F]: (A) ovigerous individual from reef caves off Porto de Galinhas, Pernambuco, northeastern Brazil, photographed in a laboratory aquarium; (B) non-ovigerous individual from Guarapari, Espírito Santo, eastern Brazil, photographed in a plastic bag after capture; (C) ovigerous individual in situ off Sal, Cape Verde; (D), ovigerous individual in situ off Tenerife, Canary Islands; (E, F), non-ovigerous individuals from Kimbe Bay, Papua New Guinea, in vitro (E) and in situ (F). Photographic credits: A, Bruno Giraldes; B, C, Peter Wirtz; D, Sergio Hanquet; E, F, Antonio Baeza. 


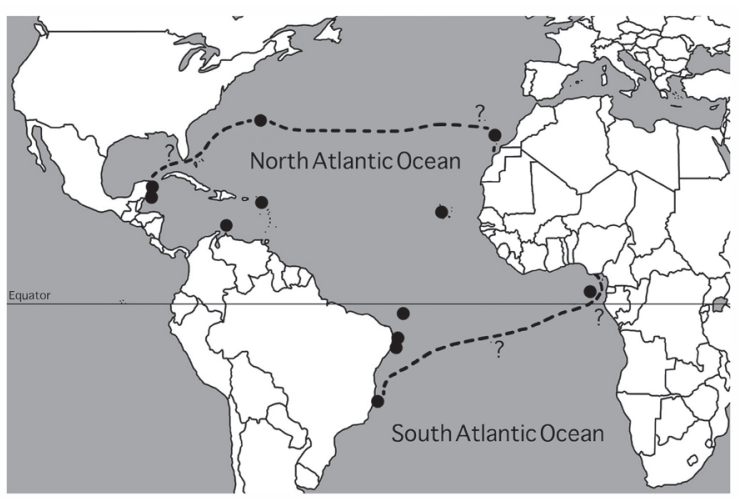

Figure 3. Distribution of Janicea antiguensis (Chace, 1972) based on previous and present confirmed records (Antigua, Bermuda, Yucatan, Cozumel, Fernando de Noronha, Pernambuco, Espírito Santo, São Tomé, Cape Verde), and underwater photographs (Bonaire, Canary Islands).

Brazil: Fernando de Noronha, Pernambuco and Espírito Santo (Ramos-Porto and Coelho, 1993; present study); in Pernambuco presently known from coastal reefs off Porto de Galinhas and Tamandaré, but most likely occurring on all reefs of the Brazilian "coral coast" extending from about $6^{\circ} \mathrm{S}$ to $10^{\circ} \mathrm{S}$ (Maida and Ferreira, 1997); in Espírito Santo known from coastal reefs off Guarapari, $-20^{\circ} \mathrm{S}$ (material collected by P. Wirtz).

Habitat: The reefs off Porto de Galinhas (main study area) run in lines parallel to the coast, serving as substrate for development of hermatypic corals and seaweeds (Manso et al., 2003). The depth between the reef formations rarely exceeds $10 \mathrm{~m}$. The reef walls have an abundance of smaller cavities and larger caverns and caves, many of them interconnecting beneath the reef flat, thus forming a maze of galleries and chambers of different sizes (Laborel, 1970; Dominguez et al., 1990; Maida and Ferreira, 1997). The cave openings to the outside are rarely higher than $5 \mathrm{~m}$.

Janicea antiguensis was observed only at night, mainly on the roof, walls and floor of the inner, narrower (diameter 1-2 m) areas of larger, semi-dark caves, but also on the outer areas, near the cave openings. Other shrimps inhabiting these caves are the rhynchocinetid Cinetorhynchus rigens (Gordon, 1936), which typically occurs in small groups, and the palaemonid Brachycarpus biunguiculatus (Lucas, 1846), which is usually living solitarily.

The reef structure of southern Espírito Santo (Guarapari) is geologically different compared to that of Porto de Galinhas. These are mostly rocky reefs patchily covered with algae, sponges, and some corals. However, these reefs are also rich in shallow submarine canyons and ledges with crevices and caverns that are suitable as shelters for J. antiguensis. Elsewhere in the Atlantic Ocean, J. antiguensis occurs in similarly shelter-rich, hard bottom habitats, e.g., in crevices among large rocks, on seawalls, in shipwrecks, in anchialine caves, and in semi-dark marine caves (Hobbs III, 1994; d'Udekem d'Acoz, 2000; Wirtz and Debelius, 2003).

Biology: At the main study area off Porto de Galinhas, almost all individuals of $J$. antiguensis were observed in pairs, in many of which both partners had eggs (developing embryos) at different stage of maturation, thus suggesting a simultaneous hermaphroditism (see below). Janicea antiguensis is a timid shrimp, reacting to dive lights immediately by escaping into deep reef crevices or deeper cave areas. To do so the shrimps typically use their pleopods to swim close to the bottom, while groping the surface with their long walking legs. In complete darkness, the shrimps usually sustain themselves on their walking legs; if touched, they react with a swift abdominal contraction to escape. The diet of J. antiguensis remains to be studied, although some individuals we observed killing and feeding on hinge-beak shrimps (C. rigens) of various sizes.

\section{Discussion}

Despite the fact that $J$. antiguensis is widely distributed in the Atlantic Ocean, ranging from Mexico to Bermuda, São Tomé and Brazil (Fig. 3), the populations of this shrimp appear to be rather localised. This is certainly due to very specific habitat requirements of this species, which like all other barbouriids is confined to habitats rich 
in crevices and caves.

In Brazil, J. antiguensis is currently known from only tree localities: 1) the oceanic islands of Fernando de Noronha (Ramos-Porto and Coelho, 1993; Coelho et al., 2006; Alves et al., 2008; present study); 2) the mainland reef off Porto de Galinhas, in Pernambuco; and 3) the reefs off Guarapari - Espírito Santo (present study). The finding of $J$. antiguensis in Pernambuco and Espírito Santo extends the geographic range of this species more than 2000 $\mathrm{km}$ south from the hitherto known southern limit. It is also the most-southern record of the family Barbouriidae in the Atlantic Ocean.

The colour pattern of $J$. antiguensis is remarkably similar to that of the IndoWest Pacific barbouriid Parhippolyte misticia (originally described as Koror misticius), which also occurs in marine caves (Clark, 1989) (Figs. 2E, F). However, in P. misticia the transverse red bands on the abdomen appear to be broader than in J. antiguensis, and in addition, in $P$. misticia, the uropods have several well-defined patches of white chromatophores, which are lacking in $J$. antiguensis (cf. Figs. 2A-D and $2 \mathrm{E}, \mathrm{F})$. In contrast, the colour patterns of the western Atlantic P. sterreri and the Indo-West Pacific $P$. uveae are clearly different from the patterns of $P$. misticia and J. antiguensis (A. Anker, pers. obs.). Noteworthy, in $P$. uveae, Wear and Holthuis (1977) found differences in the colour intensity among individuals subjected to different lighting conditions, which were intensely red by day and almost transparent at night. In contrast, no significant differences in colour intensity were found between shrimps in the caves at night and shrimps kept in aquaria in the laboratory, under artificial lighting.

The presence of eggs at different stages of development in both individuals of mated pairs of $J$. antiguensis (usually one individual with freshly laid, pale-green eggs and the other with more advanced embryos approaching spawning), suggests a protandric simultaneous hermaphroditism. This type of hermaphroditism has been demonstrated in at least one other barbouriid shrimp, Parhippolyte misticia (Onaga et al., 2012), and in a number of species of the more distantly related hippolytid genera Lysmata Risso, 1816 and Exhippolysmata Stebbing, 1916 (Bauer and Holt, 1998; Bauer, 2000; Baeza and Bauer, 2004; Baeza, 2006; Braga et al., 2009; Fiedler et al., 2010). The morphological and anatomical details of the presumed hermaphroditism in $J$. antiguensis remain to be investigated. According to Kensley (1988) and d'Udekem d'Acoz (2000), the presence of numerous small eggs of $J$. antiguensis suggests an extended larval development, which may partly explain the wide distribution of this species in the Atlantic Ocean.

Despite great morphological similarity between the eastern and western Atlantic specimens of $J$. antiguensis (d'Udekem d'Acoz, 2000), the colour of fresh eggs (embryos) appears to be quite different: green in the western Atlantic (Brazil) and yellow in the eastern Atlantic (Figs. 2A, C, D). Therefore, it will be sensible to compare genetically $J$. antiguensis from both sides of the Atlantic to investigate the degree of their genetic divergence.

The decapod diversity of the northeastern Brazilian "coral coast" remains to be explored further. Observations and collections involving scuba diving are still rather infrequent and fragmentary in Brazil. However, sampling by scuba diving is an extremely important tool in studies of the diversity and ecology of subtidal reef crustaceans, especially when combined with high quality photography of the collected material.

\section{Acknowledgements}

We thank Peter Wirtz (Universidade do Algarve, Portugal), Sergio Hanquet (www. mardefoto.com, Canary Islands, Spain), and J. Antonio Baeza (Old Dominion University, USA), who provided additional colour photographs used in Fig. 2. AA thanks CAPES (Coordenação de Aperfeiçoamento de Pessoal de Nivel Superior) for financial support in the form of a postdoctoral fellowship. 


\section{References}

Alves, M.L.; Ramos-Porto, M. and Viana, G.F.S. 2008. Checklist of the decapods (Crustacea) from the Fernando de Noronha Archipelago, Brazil. Zootaxa, 1881: 43-68.

Baeza, J.A. 2006. Testing three models on the adaptive significance of protandric simultaneous hermaphroditism in a marine shrimp. Evolution, 60: 1840-1850.

Baeza, J.A. and Bauer, R.T. 2004. Experimental test of socially mediated sex change in a protandric simultaneous hermaphrodite, the marine shrimp Lysmata wurdemanni (Caridea: Hippolytidae). Behavioral Ecology and Sociobiology, 55: 544-550.

Bauer, R.T.2000. Simultaneous hermaphroditism in caridean shrimps: a unique and puzzling sexual system in the Decapoda. Journal of Crustacean Biology, 20: 116-128.

Bauer, R.T. and Holt, G.J. 1998. Simultaneous hermaphroditism in the marine shrimp Lysmata wurdemanni (Caridea: Hippolytidae): an undescribed sexual system in the decapod Crustacea. Marine Biology, 132: 223-235.

Braga, A.A.; López-Greco, L.S.; Santos, D.C. and Fransozo, A. 2009. Morphological evidence for protandric simultaneous hermaphroditism in the caridean Exhippolysmata oplophoroides. Journal of Crustacean Biology, 29: 34-41.

Chace, F.A., Jr. 1972. The shrimps of the Smithsonian Bredin Caribbean Expeditions with a summary of the West Indian shallowwater species (Crustacea: Decapoda: Natantia). Smithsonian Contributions to Zoology, 98: 1-179.

Clark, J. 1989. Koror misticius, new genus, new species (Decapoda: Hippolytidae), a cave shrimp from Palau. Journal of Crustacean Biology, 9: 445-452.

Coelho, P.A.; Almeida, A.O.; Souza-Filho, J.F.; Bezerra, L.E.A. and Giraldes, B.W. 2006. Diversity and distribution of the marine and estuarine shrimps (Dendrobranchiata, Stenopodidea and Caridea) from North and Northeast Brazil. Zootaxa, 1221: 41-62.

De Grave, S. and Fransen, C.H.J.M. 2011.
Carideorum catalogus: the recent species of the dendrobranchiate, stenopodidean, procarididean and caridean shrimps (Crustacea: Decapoda). Zoologische Mededelingen, 85(9): 195-589.

Dominguez, J.M.L.; Bittencourt, A.C.S.P.; Leão, Z.M.A.N. and Azevedo, A.E.G. 1990. Geologia do Quaternário Costeiro do Estado de Pernambuco. Revista Brasileira de Geociências, 20: 208-215.

d'Udekem d'Acoz, C. 2000. First record of Janicea antiguensis (Chace, 1972) from the Cape Verde Islands and in the eastern Atlantic (Decapoda, Caridea, Hippolytidae). Crustaceana, 73: 11631166.

Fiedler, G.C.; Rhyne, A.L.; Segawa, R.; Aotsuka, T. and Schizas, N.V. 2010. The evolution of euhermaphroditism in caridean shrimps: a molecular perspective of sexual systems and systematics. BMS Evolutionary Biology, 10: 297 doi:10.1186/1471-214810-297.

Hart Jr., C.W. and Manning, R.B. 1981. The cavernicolous caridean shrimps of Bermuda (Alpheidae, Hippolytidae and Atyidae). Journal of Crustacean Biology, 1: 441-456.

Hobbs III, H.H. 1978. The female of Barbouria cubensis (von Martens) (Decapoda, Hippolytidae) with notes on a population in the Bahamas. Crustaceana, 35: 99-102.

Hobbs III, H.H. 1994. Biogeography of subterranean decapods in North and Central America and the Caribbean region (Caridea, Astacidea, Brachyura). Hydrobiologia, 287: 95-104.

Iliffe, T.M. 1993. Fauna troglobia acuática de la Península de Yucatán. p. 673-686. In: S.I. Salazar-Vallejo and N.E. Gonzalez (eds), Biodiversidad marina y costera de México. Mexico, CNB / CIQRO.

Iliffe, T.M., Hart Jr., C.W. and Manning, R.B. 1983. Biogeography and the caves of Bermuda. Nature, 302: 141-142.

Kensley, B. 1988. New species and records of cave shrimps from the Yucatan Peninsula (Decapoda: Agostocarididae and Hippolytidae). Journal of Crustacean 
Biology, 8: 688-699.

Laborel, J. 1970. Les peuplements de madréporaires des côtes tropicales du Brésil. Annales de l'Université d'Abidjan, 2: 1-260.

Maida, M. and Ferreira, B.P. 1997. Coral reefs of Brazil: an overview. Proceedings of the 8th International Coral Reef Symposium, Panama, 1: 263-274.

Manning, R.B. and Hart Jr, C.W. 1984. The status of the hippolytid shrimp genera Barbouria and Ligur (Crustacea: Decapoda): a re-evaluation. Proceedings of the Biological Society of Washington, 97: 655-665.

Manso, V.A.V.; Corrêa, I.C.S. and Guerra, N.C. 2003. Morfologia e sedimentologia da plataforma continental interna entre as Praias Porto de Galinhas e Campos - Litoral Sul de Pernambuco, Brasil. Pesquisas em Geociências, 30: 17-25.

Mejía-Ortíz, L.M.; Yañez, G., and LópezMejía, M. 2006. Fauna of five anchialine caves in Cozumel Island, México. The National Association for Cave Diving Journal, 39: 11-15.

Onaga, H.; Fiedler, G.C., and Baeza, J.A. 2012. Protandric simultaneous hermaphroditism in Parhippolyte misticia (Clark, 1989) (Caridea: Hippolytidae): implications for the evolution of mixed sexual systems in shrimp. Journal of Crustacean Biology, 32: 383-394.

Ramos-Porto, M. and Coelho, P.A. 1993. Sinopse dos crustáceos decápodos brasileiros (família Hippolytidae). Trabalhos Oceanográficos da Universidade Federal de Pernambuco, 22: 181-189. [Dated 1991/1993, published 1993]

Wear, R.G. and Holthuis, L.B. 1977. A new record for the anchialine shrimp Ligur uveae (Borradaile, 1899) (Decapoda, Hippolytidae) in the Philippines, with notes on its morphology, behaviour and ecology. Zoologische Mededelingen, 51: 125-142.

Wicksten, M.K. 1996. Parhippolyte cavernicola, new species (Decapoda: Caridea: Hippolytidae) from the tropical eastern Pacific, with taxonomic remarks on the genera Somersiella and Koror. Journal of Crustacean Biology, 16: 201-207.
Wirtz, P. 2004. Four amphi-Atlantic shrimps new for São Tomé e Príncipe (eastern central Atlantic). Arquipélago, Life and Marine Science, 21A: 83-85.

Wirtz, P. and Debelius, H. 2003. Mediterranean and Atlantic invertebrate guide. Conchbooks, 300p. 